\title{
UPORZĄDKOWANIE PROCESU BUDOWLANEGO W FAZIE ODBIORÓW
}

\begin{abstract}
Przedstawiono charakterystyczne zagrożenia procesu budowlanego. Wykazano potrzebę uporządkowania tego procesu, do szczególnych problemów należy brak formalnych procedur odbiorowych i lekceważenie odbioru robót. Występujące awarie są efektem błędów popełnianych na wszystkich etapach procesu budowlanego. Szczególne miejsce zajmuje jednak postawa kierownika budowy oraz inspektora nadzoru inwestorskiego. Grupą szczególnego ryzyka okazały się być struktury organizacyjne oraz osoby pochodzące $\mathrm{z}$ dawnych struktur melioracji rolnych.
\end{abstract}

Słowa kluczowe: awarie budowlane, proces budowlany, kontrola jakości, procedury odbiorowe

\section{Wprowadzenie}

Awarie budowlane nie są niczym szczególnym, zwłaszcza przy znacznej intensywności realizowanych inwestycji, w tym obiektów liniowych, jednak powinny mieć one charakter losowy. Trudno jest za takie traktować sytuacje, do których doszło w wyniku jednoznacznego lekceważenia ogólnych zasad realizacji procesu budowlanego. Konsekwencje usterek procesu budowlanego nie mogą być ograniczane do awarii. Występują sytuacje, gdy w zasadzie formalnie inwestycja została zrealizowana poprawnie, jednak normalna eksploatacja obiektu napotyka na bardzo duże ograniczenia, a niekiedy jest wręcz niemożliwa. W skrajnym przypadku gotowy (i formalnie przekazany) obiekt ulega dewastacji.

\section{Błędy projektowania}

Dominująca przyczyną awarii budowlanych jest dokumentacja projektowa, w szczególności konsekwencje lekceważenia formalnych wymagań prawa bu-

\footnotetext{
${ }^{1}$ Ziemowit Suligowski, Politechnika Gdańska, Wydział Inżynierii Lądowej i Środowiska, ul. Narutowicza 11/12, 80-233 Gdańsk, tel. +48 58 3471409, e-mail: zsuligow@pg.gda.pl
} 
dowlanego [12] oraz regulacji szczegółowych [6, 8, 9, 11]. Szczególnej uwagi wymaga powszechnie niedoceniana dokumentacja fazy projektu koncepcyjnego oraz sporządzana na jej podstawie Specyfikacja Istotnych Warunków Zamówienia (SIWZ). Pozwala ona wprowadzić istotne ograniczenia dopuszczalnych rozwiązań, co zresztą jest warunkowo (bez wskazywania konkretnego wykonawcy, wymagania mogą być ostrzejsze niż normowe) akceptowane przez Krajową Izbę Odwoławczą przy Urzędzie Zamówień Publicznych [5].

Źródłem wielu z późniejszych problemów eksploatacyjnych są również decyzje zapadające $\mathrm{w}$ fazie projektu, $\mathrm{w}$ tym pomijanie specyficznych (unikatowych) cech konkretnych wyrobów poszczególnych wytwórców. Inny problem to lekceważenie niezbędnych wymagań dla rozwiązań sprecyzowanych w SIWZ. Kolejne wynikają z dodatkowych oszczędności - głównie kosztem jakości materiałów i technologii - wprowadzanych przez wykonawców.

Praktycznie zdecydowana większość awarii obiektów liniowych (zwłaszcza kanalizacyjnych) wiąże się z błędami dotyczącymi oceny warunków posadowienia. Szczególnie poważne błędy popełniane są przy rozpoznaniu położenia (w tym migracji) zwierciadła wody gruntowej. Błędy posadowienia są również istotną przyczyną ograniczeń możliwości późniejszej eksploatacji.

Niezależnie jednak od błędów popełnianych w trakcie projektowania wiele do życzenia pozostawia ciąg dalszy procesu budowlanego. Ostatecznie to w trakcie realizacji ujawniają się różnice pomiędzy warunkami rzeczywistymi a projektowymi. W takiej sytuacji przewidziane są odpowiednie procedury zmian, korzystne z punktu widzenia kierownika budowy i tylko może dziwić, że są zbyt rzadko wykorzystywane (por. [2]). Ponadto szereg podejmowanych działań i zaniechań (rozwiązania zastępcze, podmiany na tańsze materiały, ograniczenia zakresu prac) w trakcie realizacji rzutuje na warunki i możliwości późniejszej eksploatacji.

\section{Odstępstwa od projektu na budowie}

Odstępstwa od rozwiązania projektowego są przy większych inwestycjach praktycznie nieuniknione. Zostało to uwzględnione w ustawie Prawo budowlane [12], gdzie opisano procedury ich legalizacji. Przyjęto rozwiązanie stosunkowo proste, $\mathrm{z}$ reguły legalizacja nie powoduje poważniejszego zakłóceniem realizacji inwestycji. Jednak w złej tradycji przyjęła się milcząca akceptacja daleko idących niezalegalizowanych odstępstw, w tym zwłaszcza przez inspektorów nadzoru inwestorskiego jednoznacznie działających wbrew interesom reprezentowanego przez siebie inwestora. Ma to również miejsce w sytuacjach oczywistych, gdy sporządzający dokumentację powykonawczą uprawniony geodeta po prostu nie mógłby nie wykryć różnic.

W zasadzie trudno jest wymienić, jakie odstępstwa od rozwiązania projektowego nie są prawdopodobne. Charakterystyczne przykłady to: 
- przeniesienie kanału na przeciwną stronę ulicy bez jakiegokolwiek udokumentowania samego faktu,

- „usuwanie” kolizji przewodu kanalizacji grawitacyjnej z siecią gazową poprzez redukcję (kształtką!) jego średnicy (do Ø $120 \mathrm{~mm}$ !) i przepchnięcie „od spodu” (przy okazji dość skutecznie uszkodzono izolację na istniejącym stalowym przewodzie gazowym),

- zastąpienie markowych studzienek rewizyjnych o określonych właściwościach „kombinacją” dość przypadkowych kształtek i prostek,

- istotna redukcja w stosunku do zapisanych w projekcie średnic kanalizacyjnych studzienek rewizyjnych (pojawia się też konflikt opisu średnic przy studzienkach a teleskopowym osadzeniem zwieńczenia zawężającym średnicę podstawową),

- zbyt duże odległości pomiędzy kanalizacyjnymi studzienkami rewizyjnymi, niedostosowane do możliwości eksploatatora,

- zastępowanie studzienek w miejscach krytycznych (zwłaszcza przy zmianach kierunku) kształtką i co najwyżej studzienką przelotową z prostą kinetą,

- zastępowanie właściwych kinet korytami ,wyrobionymi” w betonie butelką w lepszym wariancie przez wyciśnięcie kawałkiem rury,

- zastąpienie projektowanych studzienek rewizyjnych tańszymi rozwiązaniami o innych, mniej korzystnych cechach użytkowych,

- niewłaściwe rozwiązania połączeń przewodów ze studzienkami rewizyjnymi, komorami przepompowni ścieków, itp.,

- zastąpienie projektowanej przepompowni, o określonym poziomie zabezpieczeń, rozwiązaniem tańszym, o niższym poziomie bezpieczeństwa a nawet w ogóle rezygnacja z niego,

- przesunięcie położenia kanału o 70 metrów,

- ułożenie kolektora grawitacyjnego z „falką” dna w wysokości ok. 1,5 metra, uzyskaną na odcinku o długości niespełna $300 \mathrm{~m}$,

- korygowanie położenia rur z tworzyw sztucznych „na desce” z podsypywaniem piasku od spodu,

- niezgodne z zasadami wykuwanie otworów przyłączeniowych do kinet (w skrajnych przypadkach praktyczne zniszczenie „szklanki” studzienki),

- łączenie kanałów ze studzienkami (komorami, itp.) ,na sztywno” bez możliwości kompensacji osiadań,

- wypełnianie otworów w płaszczach studzienek przypadkowym materiałem (w tym gruzem).

Szczególnej uwagi wymaga to, że wprawdzie decyzje zapadały na budowach, to jednak (przynajmniej formalnie) funkcjonowali inspektorzy nadzoru inwestorskiego i za każdym razem potwierdzali zgodność wykonania z zatwierdzonym projektem. Ponadto zbyt często mamy do czynienia z nieodpowiednim składowaniem elementów na placu budowy i w konsekwencji ich uszkodzeniami. 
Problemem o wyjątkowym znaczeniu pozostaje brak zgodności projektowych warunków posadowienia ze stanem rzeczywistym. Może to być zdarzenie losowe, jak też efekt nadmiernego ograniczenia zakresu prac przedprojektowych, czy też ich niestarannego wykonania. Na problemy związane z ustaleniem właściwego położenia zwierciadła wody gruntowej zwraca uwagę Raganowicz [6]. Ponadto podłoże ulega zmianom z upływem czasu i ocena w fazie projektu nie musi być niezmienna.

Zwraca uwagę, że w skrajnym przypadku wykonawca nie potrafił odróżnić podłoża torfowego od piaszczysto-gliniastego występującego w projekcie. Lokalny doświadczony projektant nie potrafił (już po awarii) opracować odpowiedniego posadowienia, chociaż na przedmiotowym terenie podłoże torfowe jest dość powszechne.

\section{Szczególne miejsce przepompowni ścieków, użyteczność obiektu}

Warunki terenowe w Polsce narzucają konieczność częstego korzystanie z przepompowni ścieków. Problem pogłębia się z powodu przyłączania do kanalizacji mniej korzystnie położonych terenów. Powszechna dostępność relatywnie tanich rozwiązań nie wymagających stałej obsługi powoduje szybki wzrost liczby eksploatowanych obiektów. Przykładowo w jednym z dużych systemów przez wiele lat funkcjonowało ok. 10 przepompowni, a obecnie jest ich ponad 160. W ramach systemów gminnych, funkcjonujących na obszarach o niskiej intensywności użytkowania, powstaje po kilkadziesiąt przepompowni.

Znaczna liczba przepompowni rozproszonych na dużych obszarach wymaga odpowiedniego rozwiązania eksploatacji, przy czym z konieczności (brak stałej obsługi) musi być ona scentralizowana. Powyższa sytuacja wymaga szczególnie sprawnego przekazu informacji o stanach awaryjnych. Praktycznie może być przyjęta następująca gradacja (od najmniej zawodnych do najbardziej zawodnych):

- automatyczne przełączenie zasilania na awaryjne źródło zasilania (prądnicę),

- sygnalizacja w dyspozytorni przerwy w zasilaniu, z równoczesną blokadą przepompowni wyżej położonych w systemie,

- sygnalizacja w dyspozytorni przerwy w zasilaniu,

- sygnalizacja przerwy w zasilaniu na zewnątrz przepompowni (sygnał świetlny, sygnał dźwiękowy),

- sygnalizacja na zewnątrz przepompowni (sygnał świetlny, sygnał dźwiękowy) przepełnienia zbiornika z pomiarem elektronicznym,

- sygnalizacja na zewnątrz przepompowni (sygnał świetlny, sygnał dźwiękowy) przepełnienia zbiornika z pomiarem mechanicznym (pływak).

Praktycznie nie jest możliwe zapewnienie podwójnego, niezależnego zasilania z sieci energetycznej. Można natomiast zbyt często mówić o podwyższo- 
nym prawdopodobieństwie awarii zasilania. Problemy niezawodności zasilania dotyczą zarówno zwartych dużych systemów, jak też rozproszonych na znacznych obszarach. W rozległych systemach, na terenach o niskiej intensywności użytkowania, może pojawić się dodatkowo problem różnych eksploatatorów sieci energetycznych, działających w ramach danego układu kanalizacji.

Ostatecznie, dla potrzeb organizacji eksploatacji, konieczne jest zapewnienie niezawodnej sygnalizacji stanu obiektów. Jako minimum należałoby przyjąć sygnalizację przerw $\mathrm{w}$ zasilaniu, przy czym $\mathrm{w}$ charakterystycznym mieszanym układzie (rys. 1). Szczególne zagrożenia wiążą się z zablokowaniem niżej położonej przepompowni przy równoczesnej pracy obiektów położonych wyżej. Wówczas występują gwałtowne napływy ścieków (cykle pracy przepompowni), a poziom zagrożenia odpowiada rzędnej terenu lokalizacji przepompowni (rys. 2). Instalacje w budynkach powinny być tak zaprojektowane, aby w przypadku przepełnienia przepompowni nie mogło dojść do zalewań.

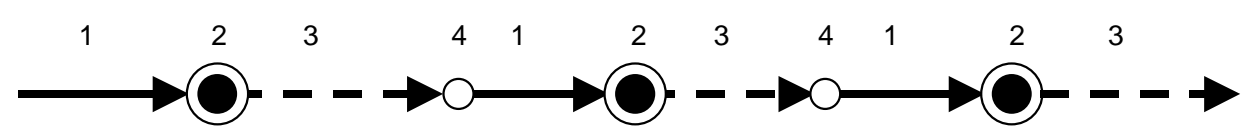

Rys. 1. Charakterystyczny układ mieszany kanalizacji: 1 - kolektor grawitacyjny, 2 - przepompownia ścieków, 3 - kolektor ciśnieniowy, 4 - komora rozprężna

Fig. 1. The distinctive arrangement of mixed sewage: 1 - gravitational sewer, 2 - sewage pumping station, 3 manifold pressure, 4 - expansion chamber

Bezwzględnie trzeba przestrzegać minimalnych standardów w zakresie bezpieczeństwa sygnalizacji, powinien tu być konsultowany przyszły eksploatator. Przykładowo w sytuacji, gdy doszło do wyjątkowo dokuczliwych awarii:

- dokumentacja fazy projektu koncepcyjnego oraz SIWZ zostały opracowane bardzo starannie,

- jednoznacznie określono wymagania w stosunku do zainstalowanej sygnalizacji,

- dokumentacja fazy projektu budowlanego została opracowana starannie zwłaszcza na tle analogicznych opracowań,

- projektant wprawdzie zamieścił w opracowaniu jako przykład odpowiedniej klasy przepompownię ścieków, ale w części opisowej nie powtórzył dosłownie zapisów SIWZ,

- wykonawca postanowił zaoszczędzić kosztem jakości wprowadzając własne rozwiązanie przepompowni,

- ostatecznie uzyskano po wielu próbach zabezpieczenia mniej więcej odpowiadające warunkom określonym w SIWZ, ale (pomijając koszty likwidacji awarii oraz koszty społeczne) koszt zakupu kolejnych wariantów rozwiązania istotnie przekroczył koszt zakupu od razu urządzenia spełniającego warunki SIWZ. 


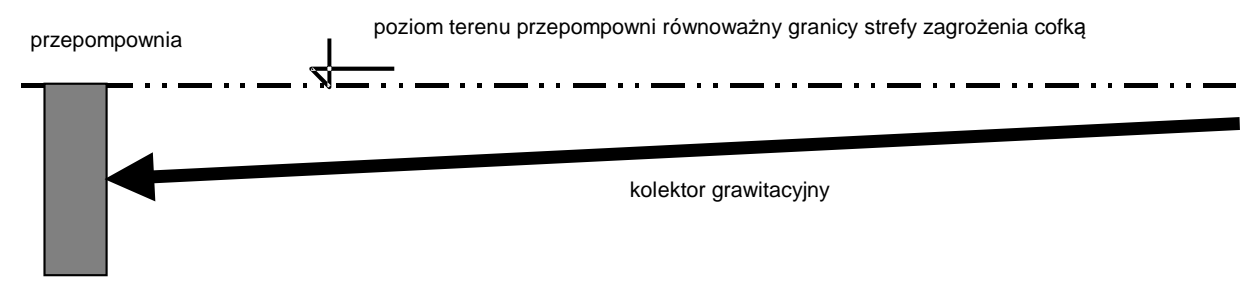

Rys. 2. Praktyczny poziom zagrożenia w przypadku zablokowania przepompowni przy równoczesnej pracy wyżej położonych obiektów

Fig. 2. Practical threat level for blocking the pumping station at the same time work higher up in the pumping station

Bardzo niepokoi, że działalność wykonawcy spotkała się z pełną akceptacją inspektora nadzoru inwestorskiego. Potwierdzeniem tego jest dokumentacja budowy, gdzie inspektor jednoznacznie potwierdzał nieprawdę, równocześnie kierownik budowy i inspektor nadzoru wdali się w długi spór z geodetami sporządzającymi niezależnie od siebie dokumentację powykonawczą i wykazującymi analogiczne samowolne odstępstwa.

\section{Zmiany w regulacjach prawnych w 2015 r.}

W roku 2015 ustawa Prawo budowlane [12] ulegała częstym zmianom, w tym odnoszącym się do zasad udzielania pozwoleń na budowę (regulacja z dnia 15 września 2015, Dziennik Ustaw 2015 poz. 1265). Zgodnie z treścią art. 29.1. pozwolenia nie wymaga m.in. budowa:

- przydomowych oczyszczalni ścieków o wydajności do 7,50 $\mathrm{m}^{3}$ na dobę,

- zbiorników bezodpływowych na nieczystości ciekłe o pojemności do $10 \mathrm{~m}^{3}$,

- przydomowych basenów i oczek wodnych o powierzchni do $50 \mathrm{~m}^{2}$,

- sieci:

- elektroenergetycznych obejmujących napięcie znamionowe nie wyższe niż $1 \mathrm{kV}$,

- wodociągowych,

- kanalizacyjnych,

- cieplnych,

- telekomunikacyjnych.

Budowa przyłączy już zgodnie z wcześniejszymi regulacjami nie wymagała uzyskania pozwolenia.

Aczkolwiek obiekty podlegają zgłoszeniu, inwestor może wystąpić z wnioskiem o wydanie decyzji o pozwoleniu na budowę. W zgłoszeniu należy określić rodzaj, zakres i sposób wykonywania robót budowlanych oraz termin ich rozpoczęcia. Zgłoszenie należy dokonać przed terminem zamierzonego rozpoczęcia robót budowlanych, a właściwy organ, w terminie 30 dni od dnia doręczenia 
zgłoszenia, może wnieść sprzeciw w drodze decyzji. Do wykonywania robót budowlanych można przystąpić, jeżeli organ nie wniósł sprzeciwu w tym terminie. W przypadku nierozpoczęcia wykonywania robót budowlanych przed upływem 3 lat od określonego w zgłoszeniu terminu ich rozpoczęcia, rozpoczęcie tych robót może nastąpić po dokonaniu ponownego zgłoszenia. W razie konieczności uzupełnienia zgłoszenia właściwy organ nakłada na zgłaszającego, w drodze postanowienia, obowiązek uzupełnienia, w określonym terminie, brakujących dokumentów, a gdy nie zostało to wykonane wnosi sprzeciw w drodze decyzji.

W konsekwencji zmodyfikowano procedurę odstępstw od projektu: istotne odstąpienie od zatwierdzonego projektu budowlanego lub innych warunków pozwolenia na budowę jest dopuszczalne jedynie po uzyskaniu decyzji o zmianie pozwolenia na budowę. Istotne odstąpienie od projektu budowlanego złożonego wraz ze zgłoszeniem budowy m.in. sieci: wodociągowych, kanalizacyjnych, cieplnych i telekomunikacyjnych, wobec którego właściwy organ nie wniósł sprzeciwu, jest dopuszczalne jedynie po uzyskaniu decyzji o pozwoleniu na budowę dotyczącej całego zamierzenia budowlanego.

Trudno jednoznacznie ocenić konsekwencje zmian, jednak biorąc pod uwagę dotychczasowe doświadczenia raczej trudno oczekiwać aby wpływały one istotnie na proces inwestycyjny. Merytoryczne kompetencje organów często były dość problematyczne (choć w ostatnim czasie zaostrzono formalne wymagania, np. w stosunku do pracowników Nadzoru Budowlanego), a zmieniona procedura dość dobrze wpisuje się w stanowisko Głównego Inspektora Nadzoru Budowlanego (GINB).

\section{Konsekwencje stanowiska Głównego Inspektora Nadzoru Budowlanego}

Na stronie internetowej GINB w dniu 06.10.2015 r zamieszczono jego stanowisko, zgodnie z którym:

- budowa instalacji elektroenergetycznych, wodociągowych, kanalizacyjnych, cieplnych i telekomunikacyjnych wewnątrz budynku nie wymaga ani uzyskania decyzji o pozwoleniu na budowę, ani dokonania zgłoszenia,

- realizacja instalacji elektroenergetycznych, wodociągowych, kanalizacyjnych, cieplnych i telekomunikacyjnych jest możliwa także w trakcie budowy budyn$\mathrm{ku}$,

- poprzednio istniała możliwość uzyskania decyzji o pozwoleniu na budowę budynku bez instalacji, jeżeli dla projektu obiektu nie przewidywano budowy instalacji, a obiekt spełniał wymagania wskazane w art. 5 ustawy - Prawo budowlane [12]; ponadto to inwestor określa zakres planowanych robót budowlanych we wniosku o pozwolenie na budowę, 
- uzyskanie pozwolenia na budowę jest prawem, a nie obowiązkiem inwestora, zatem gdy chce on wystąpić $\mathrm{z}$ wnioskiem o pozwolenie na budowę budynku bez instalacji, organ nie może mu tego prawa ograniczać, jeśli projekt jest kompletny, a projektant i sprawdzający oświadczyli, że projekt sporządzono zgodnie z obowiązującymi przepisami oraz zasadami wiedzy technicznej,

- zwolnienie jakiejś inwestycji z konieczności uzyskania pozwolenia na budowę i dokonania zgłoszenia nie oznacza, że została ona zwolniona z konieczności spełniania wymagań określonych w pozostałych przepisach ustawy czy aktach wykonawczych. W związku z powyższym do realizacji takich inwestycji (np. instalacji wewnętrznych) nadal zastosowanie znajdą przepisy technicznobudowlane, w tym szczegółowe wymagania określone w Rozporządzeniu Ministra Infrastruktury z dnia 12 kwietnia 2002 r. [7],

- zakres i treść projektu budowlanego powinny być dostosowane do specyfiki i charakteru obiektu oraz stopnia skomplikowania robót budowlanych,

- dodatkowo zakres i treść projektu budowlanego powinny być dostosowane do specyfiki i charakteru obiektu oraz stopnia skomplikowania robót budowlanych: zgodnie zaś z $\$ 7$ ust. 1 Rozporządzenia Ministra Transportu, Budownictwa i Gospodarki Morskiej z dnia 25 kwietnia 2012 r. [6] wymagania rozporządzenia należy spełnić uwzględniając właściwości danego obiektu budowlanego, takie jak przeznaczenie, sposób użytkowania oraz rodzaj i specyfikę obiektu budowlanego. Projektant powinien się przy tym kierować przede wszystkim art. 5 ust. 1 ustawy Prawo budowlane [12], określającym wymagania, jakie musi spełniać obiekt budowlany. Tym samym, jeśli projektowany obiekt spełnia te wymagania bez instalacji wewnętrznych lub bez instalacji konkretnego rodzaju, projektant nie ma obowiązku zamieszczać ich w projekcie budowlanym. Ponadto instalacje te mogą być realizowane osobno bez konieczności uzyskania pozwolenia na budowę,

- natomiast pomimo braku obowiązku sporządzania projektu budowlanego dla ww. instalacji, zgodnie z wolą inwestora, poszczególne instalacje nadal mogą być zamieszczane w projekcie budowlanym,

- instalacje będą również zamieszczane w projekcie budowlanym w sytuacji, gdy w ocenie projektanta przeznaczenie, sposób użytkowania oraz rodzaj i specyfika obiektu budowlanego, konkretne przepisy lub inne okoliczności, np. wymóg zasilania w energię elektryczną z sieci, będą skutkowały koniecznością opracowania projektu lub schematu instalacji.

$\mathrm{W}$ ślad za powyższym pismem $\mathrm{z}$ dnia $12.10 .2015 \mathrm{r}$. skierowanym do wszystkich wojewodów pismo GINB przypomina, że „organ rozpatrujący wniosek o pozwolenie na budowę, lub zgłoszenie budowy, nadal nie ma prawa ingerować w zawartość merytoryczną załączonego projektu architektoniczno-budowlanego. Nie może więc ocenić także, czy projekt architektoniczno-budowlany prawidłowo zawiera bądź nie zawiera instalacji wewnętrznych”. 
Bardzo prawdopodobnie dla oszczędności znaczna część projektów nie będzie zawierać projektów instalacji. GINB można w jakimś stopniu postrzegać jako ocenę dotychczasowej dość powszechnej (zresztą z bardzo różnymi skutkami) praktyki na terenach o niskiej intensywności użytkowania przy okazji wprowadzania na nie infrastruktury.

Opierając się na dotychczasowych doświadczeniach z tego typu realizacjami jako główne zagrożenie można traktować:

- brak oceny relacji rzędnych przyborów kanalizacyjnych (w tym wpustów) w stosunku do rzędnych sklepień przewodów ulicznych,

- brak identyfikacji strefy zagrożenia cofką, np. w wyniku zablokowania przepompowni ścieków,

- trudności z prawidłowym określeniem lokalizacji oraz rodzaju urządzeń [4] przeciwzalewowych.

Dodatkowym problemem staje się ochrona przed odorami - możliwość odprowadzenia gazów z kanału do przykanalika oraz przewietrzenia przez instalacje domowe. Jednak już samo dopuszczenie stosowania zaworów napowietrzających $w$ instalacjach na terenach o niskiej intensywności użytkowania jest mocno problematyczne, zbyt często w ogóle nie wykonuje się pionów wentylowanych. W odniesieniu do instalacji wodociągowych efektem braku odpowiednich projektów może być powiększone zagrożenie skażeniami w wyniku cofki.

Jakimś rozwiązaniem kompromisowym mogłoby być:

- bezwzględne przestrzeganie zasady przyłączania nieruchomości przez kanalizacyjną studzienkę rewizyjną,

- wprowadzenie zapisu o obowiązkowym zaopatrywaniu pionów w wywiewki,

- wprowadzenie zapisu o obowiązku stosowania w strefach zagrożonych zalaniem automatycznych urządzeń przeciwzalewowych (rys. 3),

- deklarowanie braku odpowiedzialności za skutki w przypadku automatycznych urządzeń przeciwzalewowych instalowanych dopiero w budynku, względnie ograniczenie się do sterowanych ręcznie,

- zwiększenie wymagań w stosunku do zaworów antyskażeniowych [3] montowanych na przyłączach wodociągowych.

\section{Problem odbioru}

Obowiązek odbioru inwestycji jest zapisany w ustawie [12] i zaliczony do obowiązków inwestora: „należy zorganizowanie procesu w tym zapewnienie: opracowania projektu budowlanego (i stosownie do potrzeb innych projektów), objęcia kierownictwa budowy przez kierownika budowy, opracowania planu bezpieczeństwa i ochrony zdrowia, wykonania i odbioru robót budowlanych przez osoby o odpowiednich kwalifikacjach zawodowych". 


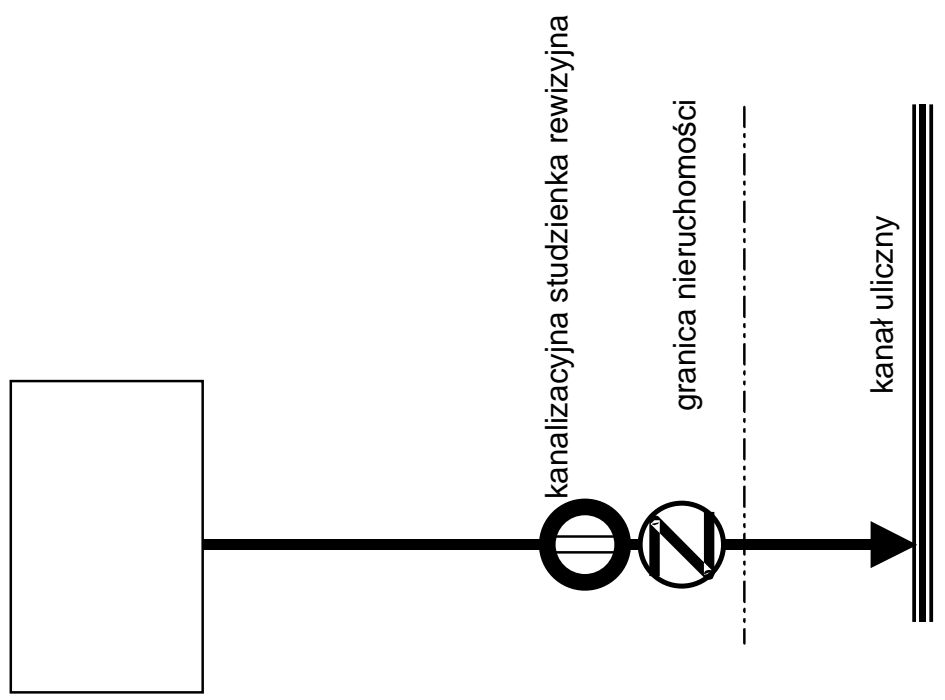

Rys. 3. Ogólna zasada stosowania zamknięcia przeciwzalewowego

Fig. 3. The general principle of the use of closing against flooding

Na kierownika budowy nałożono obowiązek zgłoszenia inwestorowi do sprawdzenia lub odbioru wykonanych robót ulegających zakryciu, bądź zanikających oraz zapewnienie dokonania wymaganych przepisami lub ustalonych w umowie prób i sprawdzeń instalacji, urządzeń technicznych i przewodów kominowych przed zgłoszeniem obiektu budowlanego do odbioru oraz zgłoszenia obiektu budowlanego do odbioru odpowiednim wpisem do dziennika budowy oraz uczestniczenie w czynnościach odbioru i zapewnienie usunięcia stwierdzonych wad.

Natomiast na inspektora nadzoru nakłada się m.in. obowiązek sprawdzania i odbioru robót budowlanych ulegających zakryciu lub zanikających, uczestniczenia $\mathrm{w}$ próbach i odbiorach technicznych instalacji, urządzeń technicznych i przewodów kominowych oraz przygotowania i udziału w czynnościach odbioru gotowych obiektów budowlanych i przekazywanie ich do użytkowania.

Do dokumentacji budowy zaliczono m.in. „protokoły odbiorów częściowych i końcowych", ale nie nałożono obowiązku sporządzania protokołów ani ich formy, ani nie określono zasad prowadzenia odbiorów (jednoosobowo, czy komisyjnie). W praktyce co najmniej ostatnich lat często:

- kierownik budowy zgłasza wykonane prace do odbioru,

- odbiera je jednoosobowo inspektor nadzoru inwestorskiego,

- nie sporządza się protokołu odbioru poprzestając na lakonicznym wpisie do dziennika budowy.

Ostatecznym efektem są wadliwe realizacje, niezgodnie z założeniami projektowymi czy też rzeczywistymi warunkami. Obiekty mogą mieć gorsze para- 
metry użytkowe, w skrajnych przypadkach mogą nie nadawać się do eksploatacji. Zwraca uwagę dwuznaczna rola wielu spośród inspektorów nadzoru inwestorskiego. Zaskakuje łatwość poświadczania nieprawdy w dokumentacji budowy, czy też wręcz jej fałszowanie.

\section{Procedura odbioru}

Odbiór robót budowlanych jest jednym z kluczowych etapów procesu inwestycyjnego, potwierdzającym wykonanie, otwierającym wykonawcy prawo do żądania wynagrodzenia. Jednak może równocześnie wykazać braki oraz otwiera bieg terminów rękojmi. Często odbiór staje się początkiem sporów między inwestorem a wykonawcą, jego właściwa organizacja zapewnia bezpieczeństwo wszystkich stron zaangażowanych w proces inwestycyjny. W przypadku inwestycji współfinansowanych z różnych funduszy występuje dodatkowo element trwałości efektu, praktycznie oznacza to możliwość powtórnego odbioru inwestycji nawet po upływie 5 lat od jej ukończenia ze wszelkimi konsekwencjami finansowymi wynikającymi z braku zachowania efektu (ograniczenie, nawet cofnięcie, dofinansowania oraz naliczenie odsetek od zakwestionowanych kwot).

Konieczne jest wprowadzenie stosownych zapisów do umowy na roboty budowlane. Przykładem lokalnych regulacji jest opracowanie gdańskie [1] przygotowane na zlecenie Zarządu Dróg i Zieleni. Uwzględniono w nim:

- wymagania odnośnie materiałów do wykonania regulacji wysokościowej,

- wymagania dotyczące sprzętu,

- wymagania dotyczące transportu,

- dokładne zasady wykonania robót,

- wymagania dotyczące zasad kontroli jakości robót,

- ogólne zasady obmiaru robót,

- ogólne zasady odbioru robót,

- ustalenia dotyczące podstawy płatności,

- zestawienie norm przywołanych w specyfikacji technicznej.

Specyfikacja [1] stanowi dokument przetargowy i kontraktowy przy zlecaniu i realizacji robót na drogach publicznych oraz wewnętrznych zlokalizowanych w granicach administracyjnych Miasta Gdańska (w którego imieniu działa Zarząd Dróg i Zieleni). Dla jednoznaczności zamieszczono określenia podstawowe (z odniesieniem się do pozostałych) zestawienie przepisów.

Procedury związane z odbiorem muszą być dostosowane do wymagań specyficznych dla poszczególnych grup materiałowych. Praktyka obrotu gospodarczego w budownictwie wykształciła kilka rodzajów odbiorów, w tym:

- odbiór końcowy,

- odbiór robót ulegających zakryciu albo zanikających zgłoszonych do odbioru przez kierownika budowy, 
- odbiór przejściowy (od podwykonawców robót, w szczególności poszczególnych instalacji), które w przyszłości będą przedmiotem odbioru między inwestorem a wykonawcą robót,

- odbiór częściowy - odbiór określonych etapów robót, w ramach jednego przedmiotu odbioru, stwierdzone protokołami stanu robót, stanowiącymi podstawę rozliczenia za dany etap,

- odbiór pogwarancyjny.

Do udziału w odbiorze robót budowlanych zobowiązani są:

- kierownik budowy, do którego obowiązków należy zgłoszenie obiektu do odbioru odpowiednim wpisem do dziennika budowy,

- inwestor (osobiście, lub przez wskazanego pełnomocnika),

- odpowiedni rzeczoznawcy budowlani, przy czym wg ustawy Prawo budowlane [12] zapewnienie odbioru przez osoby o odpowiednich kwalifikacjach należy do obowiązków inwestora,

- inspektor nadzoru inwestorskiego (o ile został powołany), stąd inspektor nadzoru nie jest i nie powinien być pełnomocnikiem inwestora,

- kierownicy robót.

Przepisy nie nakładają obowiązku sporządzenia protokołu odbioru przedmiotu umowy o roboty budowlane, jednak zgodnie z art. 462 k.p.c. każdy wykonawca spełniający świadczenia może domagać się sporządzenia protokołu traktując go jako formę pokwitowania. Brak może stwarzać istotne problemy przy rozwiązywaniu zagadnień spornych, rozpoczynając od usuwania wad. Przy braku protokołu skutki prawne związane z odbiorem należy liczyć od chwili oddania przedmiotu umowy, nawet gdyby po pewnym czasie został sporządzony protokół dokumentujący fakt odbioru.

\section{Wymagania formalne}

Istniejące $\mathrm{w}$ systemie prawnym braki i niedomówienia, związane z odbiorem inwestycji, stwarzają szereg problemów w przyszłości. Powinny one odpowiadać poziomowi obiektu oraz aktualnym warunkom budowlanym i opierać się na jednoznacznych zasadach. Jedynym rozwiązaniem w obecnej sytuacji jest wprowadzanie jednoznacznych zapisów do kontraktów z wykonawcą.

Brak jest aktualnych warunków technicznych odbioru, zamieszczonych w Dzienniku Ustaw w postaci „,warunków” wydanych przez właściwego ministra, co powinno stwarzać podstawę do traktowania zapisów jako obligatoryjnych. Jest to szczególnie istotne w odniesieniu do małych systemów, zwłaszcza na terenach o rozproszonej zabudowie, gdzie trudno spodziewać się dostatecznej jakości eksploatacji. Brak przy tym aktualnych standardów w zakresie eksploatacji infrastruktury. 


\section{Propozycja rozwiązania}

Terminy oddawania obiektów podporządkowane są obecnie w znacznym stopniu zachowaniu dotacji, czego efektem jest częsta fikcyjność odbiorów końcowych. Znacząca część zaistniałych zdarzeń została jednak zainicjowana przez sytuacje stworzone znacznie wcześniej - jeszcze w fazie przygotowania inwestycji oraz realizacji robót zanikających. Dotychczasowa praktyka wymusza traktowanie inspektora nadzoru inwestorskiego jako osoby nie zasługującej na całkowite zaufanie, potrzebna jest kontrola jego działania na budowie. W tej sytuacji procedury odbiorowe powinny być wpisane do umowy na roboty budowlane, nie można ich pozostawić samemu inspektorowi.

W szczególności wszystkie odbiory robót powinny być prowadzone komisyjnie i udokumentowane odpowiednimi protokołami. Inspektor nadzoru inwestorskiego nie powinien być uznawany przy odbiorach jako przedstawiciel inwestora. Ze względu na specyfikę funkcjonowania polskich przedsiębiorstw branżowych i ich miejsce w procesie inwestycyjnym, do komisji odbioru powinien być włączany również przedstawiciel przyszłego eksploatatora. Takie rozwiązanie powinno ograniczyć możliwość fikcyjnych kontroli na budowach oraz pozornych odbiorów i w efekcie sporządzania nieprawdziwej dokumentacji budowy.

\section{Literatura}

[1] Edel R., Pszczoła M.: Opracowanie specyfikacji technicznej regulacji wysokościowej urządzeń uzbrojenia podziemnego wodno - kanalizacyjnych, kanalizacji deszczowej oraz urządzeń gazowych w Gdańsku, Politechnika Gdańska, 2013, http://www.gdmel.pl, http://www.zdiz.gda.pl.

[2] Paprocki P., Koda E.: Zmiany w procedurach ustalania geotechnicznych warunków posadowienia obiektów budowlanych, Inżynier Budownictwa, wyd. internetowe 18. 02.2013.

[3] PN-EN 1717: Ochrona przed wtórnym zanieczyszczeniem wody w instalacjach wodociągowych i ogólne wymagania dla urządzeń zapobiegających zanieczyszczeniom przez przepływ zwrotny.

[4] PN-EN 13564: Urządzenia przeciwzalewowe w budynkach.

[5] Pozacenowe kryteria oceny ofert $w$ postępowaniu o udzielenie zamówienia publicznego, Urząd Zamówień Publicznych, Warszawa 2012.

[6] Raganowicz A.: Projektowanie urządzeń do rozsączania wód deszczowych. Poziom zwierciadła. Cz. I i Cz. II, Magazyn Instalatora, nr 9 i 11, 2015.

[7] Rozporządzenie Ministra Infrastruktury z dnia 12 kwietnia 2002 r. w sprawie warunków technicznych, jakim powinny odpowiadać budynki i ich usytuowanie: Dz. U. 2015, poz. 1422.

[8] Rozporządzenie Ministra Transportu, Budownictwa i Gospodarki Morskiej z dnia 25 kwietnia 2012 r. w sprawie szczegółowego zakresu i formy projektu budowlanego: Dz. U. 2012, poz. 462. 
[9] Rozporządzenie Ministra Spraw Wewnętrznych i Administracji z dnia 24 czerwca 1998 r. w sprawie ustalania geotechnicznych warunków posadawiania obiektów budowlanych: Dz. U. 1998, nr 126.

[10] Rozporządzenie Ministra Środowiska z dnia 23 grudnia 2011 w sprawie dokumentacji hydrogeologicznej i dokumentacji geologiczno-inżynierskiej: Dz. U. 2011, nr 291.

[11] Rozporządzenie Ministra Transportu, Budownictwa i Gospodarki Morskiej z dnia 25 kwietnia 2012 r. w sprawie ustalania geotechnicznych warunków posadawiania obiektów budowlanych, Dz. U. 2012, poz. 463.

[12] Ustawa z dnia 7 lipca 1994 r. Prawo budowlane. Tekst jednolity. Dz. U. 2013, poz. 1409, z późn. zm.; uaktualniona wersja opublikowana w styczniu 2016 r. na stronie internetowej: http://www.gunb.gov.pl.

\section{ORDERING OF THE BUILDING PROCESS ACCEPTANCE PHASE}

\section{S u m m a r y}

Characteristic risks of the building process are presented. It has been shown the need to organize this process, lack of formal acceptance procedures and disregard for the receipt of work to be the specific problems. Occurring failures are the result of mistakes made at all stages of the building process. A special place is occupied by the attitude of the building manager and the investor's supervision inspector. Particularly at risk proved to be the organizational structures and people the former existing structures of the agricultural drainage area.

Keywords: building failures, building process, quality control, acceptance procedures

DOI: $10.7862 /$ rb.2016.178

Przestano do redakcji: 01.05.2016 $r$.

Przyjęto do druku: 28.06.2016 r. 